\title{
PENGEMBANGAN MEDIA DEMONSTRASI KIMIA UNTUK MENINGKATKAN KUALITAS PEMBELAJARAN PEMISAHAN KIMIA MELALUI LESSON STUDY
}

\author{
Muti'ah $^{1 *}$, I Nyoman Loka ${ }^{2}$ dan Muntari ${ }^{3}$ \\ ${ }^{12}$ Program Studi Pendidikan Kimia, Universitas Mataram. Jalan Majapahit No. 62 \\ Mataram, NTB 83112, Indonesia. \\ * Coressponding Author. E-mail: mutiah_fkip@unram.ac.id
}

\author{
Received: 3 September 2021 Accepted: 30 November 2021 Published: 30 November 2021 \\ doi: $10.29303 /$ cep.v4i3.2923
}

\begin{abstract}
Abstrak
Penelitian ini tentang penerapan media demonstrasi kimia untuk meningkatkan kualitas pembelajaran Pemisahan Analitik. Penelitian ini dilakukan selama dua siklus melalui pendekatan Lesson Study yang terdiri dari perencanaan/plan, pelaksanaan-observasi/do, dan refleksi/see. Pengumpulan data diperoleh berdasarkan hasil wawancara yang bersifat kolaboratif dalam diskusi antar tim pada kegiatan plan, do dan refleksi, serta data hasil belajar mahasiswa. Hasil analisis data dalam kegiatan plan dan see selama 2 siklus menunjukkan adanya perubahan dinamis yang ditunjukkan oleh: (1) perubahan sikap positif tim pengajar: terbentuk rasa kolegalitas, bersikap terbuka, belajar dari pengalaman nyata, adanya kerjasama untuk mengembangkan, saling membagi ide baru dan membuktikannya. (2) Ditemukannya 4 formulasi efektif dalam penggunaan media demonstrasi kimia-gambar power point yaitu: penguasaan materi, terjangkau seluruh mahasiswa, sinkronisasi hasil demonstrasi-gambar pada power point, dan ketersediaan waktu. (3) Adanya peningkatan perhatian, aktivitas, dan motivasi dalam pembelajaran. (4) adanya peningkatan pemahaman mahasiswa dalam mengidentifikasi fasa gerak dan fasa diam, mengevaluasi terjadinya pemisahan komponen, dan interpretasi data percobaan dari 51 hingga 82 pada siklus I dan dari 49 menjadi 84 pada siklus II. Kesimpulan dari penelitian ini menunjukkan bahwa pendekatan Lesson Study dapat meningkatkan kemampuan dosen dalam mengembangkan media demonstrasi kimia pada pembelajaran Pemisahan Analitik yang berkualitas
\end{abstract}

Kata Kunci: Demonstrasi Kimia, Kualitas Pembelajaran, Lesson Study

\section{Development of Chemical Demonstrations Media to Improve Quality Analytical Separation Learning Through Lesson Study}

\begin{abstract}
Research on implementation of chemical demonstrations media to improve the quality of Analytical Separation learning. The study was conducted over two cycles through Lesson Study approaches of planning/plan, implementation - observation/do, and reflection/see. The collection of data obtained by interview collaboratively in discussions between the teams on the plan, do and reflection activity, as well as student learning outcomes data. The results of the analysis data on the plan and see activity for 2 cycles indicate a dynamic change shown by (1) positive attitude change on teaching team: having collegiality, opennes, learning from real experiences, the cooperation to develop, share new ideas and prove it (2) Discovery of four effective formulations in the use of chemical demonstrations mediadrawing power point, namely: mastery of the material, affordable all students, synchronization of demonstration results and drawing on the power point, and time availability. (3) An increase in attention, activity, and motivation in learning. (4) An increased understanding of the student in identifying the mobile phase and stationary phase, evaluating the separation of the components, and the interpretation of experimental data, from 51 to 82 in the first cycle and from 49 to 84 on the second cycle. The conclusion of this research indicate that the Lesson-Study approach can improve the ability of teachers to develop of chemical demonstration media at the Analytical Chemical Separation teching learning.
\end{abstract}

Key words : Chemical demonstration, Teaching - Learning Quality, Analytical Separation, Lesson Study 


\title{
Chemistry Education Practice, 4 (3), 2021 - 288
}

\author{
Muti'ah, Loka, Muntari
}

\section{PENDAHULUAN}

Kimia analitik adalah bagian dari ilmu kimia yang mempelajari tentang cara menentukan apa dan berapa jumlahnya, oleh sebab itu konsep kimia analitik cukup penting dalam ilmu kimia (Valcarcel, 1992). Hal tersebut karena bidang ini mampu memberikan konsep dasar analisis kimia, pemisahan zat, penyusunan metode, teknik dan prosedur analisis serta mengaplikasikannya dalam kehidupan (Valcarcel \& Luque de Castro, 1995).

Matakuliah Pemisahan Analitik merupakan salah satu bagian dari matakuliah kelompok bidang kimia analitik. Pemisahan analitik merupakan matakuliah yang menjembatani antara matakuliah dasar-dasar kimia analitik dan kimia instrumen, sehingga perlu mendapat perhatian. Namun demikian dari hasil refleksi Tim pengajar menunjukkan bahwa kualitas pembelajaran masih rendah. Hal ini ditunjukkan oleh beberapa hal yaitu: perhatian, motivasi, kedisiplinan, kreativitas dan kerja sama mahasiswa dalam pembelajaran masih rendah, adanya kesalahan konsep dan tidak mamapu menghubungkan antara teori dan praktek. Hal tersebut diduga karena pembelajaran yang selama ini menggunakan metode konvensional yaitu ceramah dan diskusi dan praktikum yang tidak terintegrasi dalam perkuliahan.

Berdasarkan permasalahan tersebut di atas maka Tim pengajar sepakat untuk menerapkan metode demonstrasi dalam pembelajaran Pemisahan Analitik dengan menggunakan media "Demonstrasi Kimia". Demonstrasi kimia telah terbukti sebagai media yang tepat pada pembelajaran, karena mampu membangkitkan perhatian dan motivasi siswa, (Roadruck 1993)embangkitkan kedisiplinan, kreativitas dan kerjasama antar siswa (Miller, 1993; Milne \& Otieno, 2007), merangsang berpikir kritis dan mengatasi kesalahan konsep (Chiappetta dan Koballa 2002, Muti'ah, 2016) dan mamapu menghubungkan antara konsep/teori dengan praktek dalam kehidupan (Meyer et al., 2003; Clermont et al., 1994).

Disamping memiliki kelebihan, beberapa peneliti melaporkan adanya kendala dalam penggunaan metode demonstrasi. Sebagaimana dilaporkan oleh Pierce dan Pierce (2007) bahwa demonstrasi kimia yang dilakukan dalam kelas besar, maka siswa tidak dapat belajar dari apa yang sebenarnya didemostrasikan. Baddock dan Bucat (2008) menyatakan bahwa bila seorang pengajar tidak benar dalam melaksanakan demonstrasi (terutama adalah demonstrasi yang sangat menarik) dan keliru dalam penjelasanya, maka dapat menjadikan miskonsepsi pada pemahaman siswa

Berdasarkan penjelasan di atas, maka kendala dalam penerapan metode demonstrasi adalah berkaitan dengan profesionalisme seorang dosen dalam parktek pembelajaran dikelas. Menurut Chokshi dan Fernandez (2005) profesionalisme seorang pengajar dapat dilakukan dengan menerapkan kegiatan Lesson Study. Hal tersebut dikarenakan dengan kegiatan Lesson Study seorang pengajar atau dosen secara berkolaborasi terlibat langsung dalam perencanaan, pengamatan praktek dan analisis hal-hal yang berharga yang diperoleh selama kegiatan mengajar (Cochran-Smith dan Lytle, 1999; Putnam dan Borko, 2000).

\section{METODE}

Penelitian ini dilaksanakan di Program Studi Pendidikan Kimia, Jurusan PMIPA, FKIP Unram. Subyek dalam penelitian ini adalah Tim Dosen pengampu matakuliah Pemisahan Analitik dan Mahasiswa yang mengikuti matakuliah Pemisahan analitik. Obyek dalam penelitian ini adalah: (1) perhatian dan aktivitas mahasiswa, motivasi, dan hasil belajar mahasiswa, (2) Kemampuan Tim Dosen dalam menerapkan metode demonstrasi, terutama dalam hal: perencanaan/plan, pelaksanaanobservasi/do, refleksi pembelajaran/see

Penelitian ini diracang sesuai dengan pendekatan Lesson Study dan Model Penelitian Tindakan Kelas. Pendekatan Lesson Study pada dasarnya merupakan kesatuan proses kegiatan nyata oleh Tim Dosen yang terdiri dari 3 tahap, yaitu: plan (perencanaan pembelajaran), do (pelaksanan pembelajaran dan observasi), see (analisis dan refleksi). (Hendayana et al,. 2006) Tindakan yang dilakukan adalah menerapkan metode demonstrasi dalam pembelajaran. Berdasarkan materi perkuliahan yang diteliti, maka penelitian ini dilakukan dalam dua siklus, yaitu: siklus 1: Kromatografi Lapis Tipis dan siklus 2: Kromatografi Kolom

\section{Plan/Perencanaan Pembelajaran}

Dalam kegiatan perencanaan (plan) seorang anggotan tim menjadi dosen model sedangakan yang lain sebagai observer. Pada tahap ini dosen model secara umum menyampaikan perangkat pembelanjaran yang telah dibuat (RPP, media/"Demonstrasi Kimia Kromatografi Lapis Tipis", alat penilaian) untuk di kaji bersama secara kolaboratif dalam diskusi untuk menemukan kesepakatan dalam pelaksanaan pembelajaran (Do) 
Pelaksanaan Pembelajaran (Do) dan Observasi

Dalam kegiatan pelaksanaan pembelajaran atau $D o$, seorang dosen melaksanakan pembelajaran di kelas sebagai dosen model, sedangkan yang lain orang dosen menjadi observer. Dosen model melakukan pengajaran/perkuliahan sesuai dengan apa yang telah disepakati dalam kegiatan plan, yaitu "mengajar dengan metode demonstrasi" dan observer mengamati, merekam, hal yang terjadi selama pembelajaran terutama kejadian janggal dan tidak layak yang dilakukan siswa dalam bentuk video dan dicatat sebagai notulen.

\section{Refleksi (See)}

Kegiatan refleksi merupakan kegiatan analisis dan evaluasi hasil observasi dari kegiatan pelaksanaan pembelajaran. Dalam kegiatan ini bukan hanya berisi tanggapan dari observer, tetapi juga kritik. Pada tahapan refleksi dosen model melaporkan tentang bagaimana pelaksanaan pembelajaran yang telah dilakukan. Selanjutnya observer menyampaikan hasil observasi secara nyata selama proses pembelajaran dan dilakukan pengkajian analisis berasaskan kolaboratif untuk mencapai kesepakatan bersama untuk digunakan perbaikan dalam kegiatan plan, do, dan see dalam siklus berikutnya

\section{HASIL DAN PEMBAHASAN}

Hasil penelitian dikumpulkan dari data wawancara Tim Lesson Study pada kegiatan plan dan see, tes hasil belajar mahasiswa, serta tanggapan mahasiswa dalam bentuk angket. Berdasarkan data wawancara Tim Lesson Study dapat peroleh tiga pencapaian, yaitu: (1) perkembangan sikap dan profesionalisme Tim, (2) perkembangan kemampuan Tim dalam menyusun strategi pembelajaran, (3) aktivitas pembelajaran, dan (4) hasil belajar. Secara ringkas data tersebut disajikan secara kualitatif dan kuantitatif sebagaimana tercantum dalam tabel 1 .

Tabel 1. Data Pencapaian Lesson Study Selama Siklus 1 dan 2

\begin{tabular}{llcc}
\hline Pencapaian & Siklus1 & Siklus2 \\
\hline A. & Sikap Tim & & \\
\hline 1. & Kolegalitas/kebersamaan & Cukup & Baik \\
2. & Terbuka & Baik & Baik \\
3. Menyampaikan/menerima & Cukup & Baik \\
& ide & Baik & Baik \\
4. $\quad$ Tanggung jawab & Baik & Baik \\
5. $\quad$ Mau belajar dari & Tinggi & Tinggi \\
& pengalaman & & \\
6. Motivasi belajar & & \\
\hline B. & Kemampuan Menyusun & & \\
& Strategi & & \\
1. & Merancang ide/strategi & Cukup & Baik \\
\hline
\end{tabular}

\begin{tabular}{llc}
\hline 2. Menguji ide/gagasan & Cukup & Baik \\
\hline C. Aktivitas Pembelajaran & & \\
1. Memperhatikan & $60 \%$ & $80 \%$ \\
penjelasan dosen & $0 \%$ & $8 \%$ \\
2. Bertanya pada dosen & $65 \%$ & $80 \%$ \\
3. Melakukan diskusi & & \\
$\quad$ dengan baik & & \\
\hline D. Hasil Belajar & 82 & 84 \\
\hline
\end{tabular}

Sikap Dosen Selama Kegiatan Lesson Study

Berasarkan hasil plan dan refleksi antara Tim Lesson Study pada siklus 1 dan 2, maka dapat ditunjukkan bahwa: (1) rasa kolegalitas, (2) tanggunga jawab, (3) saling memberi menerima gagasan, (4) rasa ingin maju/belajar sepanjang massa (5) terbuka telah terbentuk dalam diri masing-masing tim pengajar. Adanya sikap ingin maju dan belajar sepanjang massa ditunjukkan oleh hasil kesepakan di akhir kegiatan dimana masih ada permasalahan yang belum dapat diselesaikan dan perlu selalu dikaji. Hal ini sesuai dengan pendapat Lewis (2004) bahwa dengan Lesson Study dosen mendapat kesempatan memperdalam materi pelajaran yang ditekuninya dengan mengacu pada kurikulum dan standar yang digunakan, memilih dan memodifikasi pembelajaran, mengantisipasi pemikiran siswa, dan menganalisis tanggapan siswa.

\section{Kemampuan Dosen dalam Mengembangkan Metode Demonstrasi}

Dari hasil wawancara Tim peneliti pada siklus I dan II dapat diidentifikasi alur pengembangan metode demonstrasi, yaitu: (1) menggunakan media demonstrasi kimia yang disajikan bersama power point. (2) menggunakan media demonstrasi langsung/bukan video, tetapi hal yang bersifat konsep disajikan dalam bentuk gambar/foto dalam power point. Dalam gagasan ini belum dijelaskan teknik penyampaiannya apakah secara bersamaan atau bergantian atau dalam bentuk video. Disamping itu posisi tempat duduk mahasiswa dengan posisi meja percobaan juga belum dibahas. (3) menggunakan media demonstrasi - power point dengan posisi terjangkau seluruh mahasiswa (posisi tempat duduk mahasiswa membentuk huruf U). Untuk mensinkronisasi antara hasil pengamatan dengan gambar-konsep dalam power point, maka proses demonstrasi dilakukan secara bertahap: demosntrasi - power point, demonstrasi - power point dan seterusnya. (4) menggunakan waktu secara efisien, dengan cara melakukan uji coba/latihan dan melakukan kajian teoritik secara mendalam sebelum pembelajaran. 


\section{Chemistry Education Practice, 4 (3), 2021 - 290}

Muti'ah, Loka, Muntari

Berdasarkan hasil penelitian tersebut di atas terbukti bahwa melalui Lesson Study, seorang dosen mampu meningkatkan profesionalisme pengajar/dosen. Hal ini sesuai dengan hasil penelitian terdahulu bahwa dengan Lesson Study seorang dosen: terbantu dalam pemahaman isi materi (Lewis, 2004) bersifat terbuka, belajar dari pengalaman, berbagai ide dan pengalaman masingmasing dosen, memiliki pengetahuan yang terbuka untuk dikritik dan direvisi, disiplin dan bekerja secara profesional seumur hidup (Chokshi dan Fernandez (2005).

Berkaitan dengan pengembangan metode demonstrasi, maka Tim peneliti memformulasikan suatu penggunaan demonstrasi kimia dalam pembelajarannya mengacu pada hasil penelitian Muti'ah et al. (2017), yaitu: memadukan demonstrasi nyata yang dipadukan dengan gambar/foto yang mengandung konsep teoritik dan disajikan dalam power point (gambar 1). Hal ini bertujuan untuk dapat menjelaskan arti fisik dari gejala molekular yang terjadi pada pemisahan secara kromatografi lapis tipis.

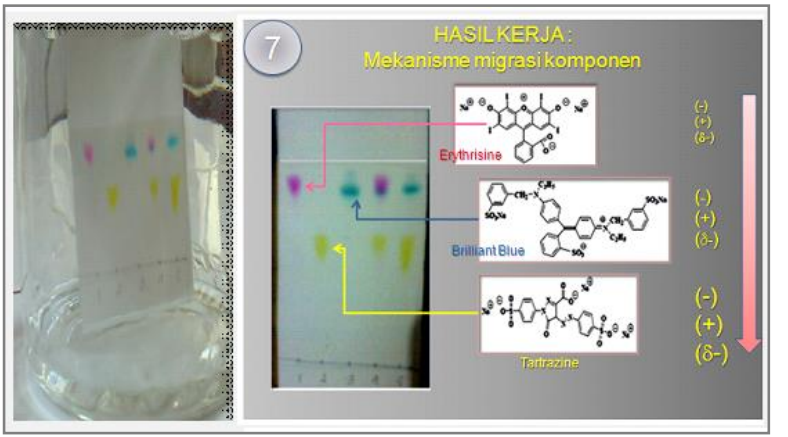

Gambar 1. Hasil demonstrasi nyata - gambar power point KLT zat warna makanan

Untuk mencapai tujuan tersebut, maka telah ditemukan 4 komponen sebagaimana tercantum pada gambar -2 .

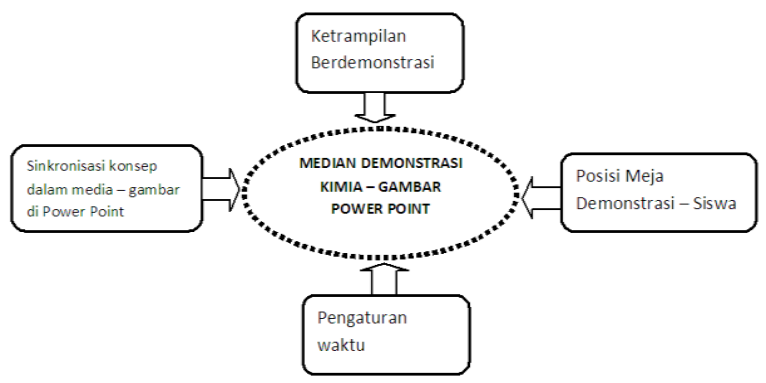

Gambar 2. Teknik pembelajaran demonstrasi kimia gambar power point pada matakuliah analytical separation
Formulasi teknik pembelajaran pada gambar 2 telah dikaji dalam kegiatan plan, dibuktikan dalamm kegiatan do/pelaksanaan pembelajaran dan dikaji dalam kegiatan see/refleksi. Formulasi tersebut adalah bahwa metode demonstrasi kimia dipadukan dengan gambar/konsep dalam power point dapat terlaksanan dengan baik bila seorang demontran menguasai materi dengan baik, terjangkau seluruh mahasiswa (posisi duduk bentuk U), adanya sinkronisasi antara hal yang didemonstrasikan dengan gambar dalam power point (secara bertahap), dan alokasi waktu yang tepat. Hasil penerapan strategi tersebut terhadap pembelajaran mahasiswa menunjukkan adanya peningkatan kualitas pembelajaran sebagaimana tercantum dalam tabel 1. Kualitas pembelajaran ditujukan dengan nilai aktivitas mahasiswa dan hasil belajar yang meningkat.

\section{Kualitas Pembelajar Mahasiswa Perhatian dan Aktivitas Pembelajaran}

Kualitas pembelajaran chemical separation ditujukkan dengan 3 indikator yaitu: perhatian dan aktivitas selama proses pembelajaran, tes hasil belajar, dan motivasi belajar. Perhatian dan aktivitas mahasiswa selama proses pembelajaran di siklus I dan II dapat ditunjukkan dari hasil kegiatan do baik oleh dosen model maupun observer. Berikut ini rangkuman hasil refleksi pada siklus I "Secara umum konsentrasi dan perhatian mahasiswa berlangsung sejak awal hingga akhir pembelajaran. Namun demikian ada beberapa catatan khusus, yaitu: (1) Masih ada beberapa mahasiswa yang mengalami kesulitan dalam mengamati percobaan/demonstrasi.

Berkaitan dengan transformasi informasi data hasil pengamatan dengan foto/gambar pada power point, masih nampak adanya kesulitan dalam penjelasannya (3) Tidak satupun mahasiswa yang mengajukan pertanyaan saat ada penjelasan (4) Baik proses maupun hasil pembelajaran sudah baik. Hal ini diindikasikan saat kerja kelompok dan hasil tes akhir. Oleh sebab itu dapat dikatakan bahwa teknik pembelajaran ini sudah tepat untuk matakuliah Pemisahan Kimia, walaupun masih ada beberapa kendala yang harus diperbaiki yaitu beberapa mahasiswa nampak kesulitan dalam memahami gambar/konsep dalam power point.

Hasil Rekaman kegiatan do pada siklus II adalah "Hampir seluruh mahasiswa dapat mengamati hasil percobaan dan media gambar/konsep dalam power point. Dosen 


\section{Chemistry Education Practice, 4 (3), 2021 - 291}

Muti'ah, Loka, Muntari

model juga mampu memadukan antara media dalam percobaan dengan gambar dalam power point. Hal ini terbukti dengan adanya alur konsep yang cukup sistematik".

Berdasarkan data hasil observasi kegiatan pembelajaran selama siklus I sampai siklus II bahwa perhatian dan aktivitas mahasiswa meningkat secara signifikan. Hal ini menunjukkan bahwa teknik pembelajaran yang disusun oleh tim Lesson Study cukup baik. Hasil penelitian ini sesuai dengan kajian yang dilakukan oleh peneliti terdahulu, yaitu bahwa metode demosntrasi dapat meningkatkan perhatian siswa dan mendorong inklusivitas, meningkatkan kemampuan dalam memprediksi, pengamatan, dan penjelasan suatu konsep dan meningkatkan kemampuan dalam mengerjakan tes hasil belajar (Shepardson et al., 1994). Disamping itu metode demonstrasi juga mampu merangsang proses berpikir siswa, meningkatkan perhatian terhadap materi pembelajaran, serta menghubungkan konsep teori dan praktek, (Lewis, 2004) sebagai pengganti praktek laboratorium/ percobaan yang terlalu mahal atau berbahaya untuk siswa, serta mengembangkan kreativitas siswa dan meningkatkan kerjasama antara siswa-guru (Miller, 1993 \& Buncick et al.,2001) juga menyatakan bahwa metode demonstrasi dapat meningkatkan aktivitas siswa, karena dengan metode ini seorang guru/pengajar akan memberikan kesempatan siswa untuk bertanya.

\section{Prestasi Hasil Belajar}

Prestasi hasil belajar mahasiswa pada siklus I dan II pada topik kromatografi lapis tipis dan kolom adsorbsi difokuskan pada kemampuan dalam: mengidentifikasi fasa gerak, fasa diam, mengevaluasi terjadinya pemisahan komponen, dan intepreatasi data hasil pemisahan. Data hasil kemampuan mahasiswa pada konsep - konsep tersebut disajikan pada tabel 2 berikut.

Tabel 2. Data Nilai rata-rata hasil belajar mahasiswa pada topik kromatografi

\begin{tabular}{lcccc}
\hline \multirow{1}{*}{ Konsep } & \multicolumn{2}{c}{ Siklus I (KLT) } & \multicolumn{2}{c}{ Siklus II (KKA) } \\
\cline { 2 - 5 } & Sebelum & Sesudah & Sebelum & Sesudah \\
\hline $\begin{array}{l}\text { Identifikasi } \\
\text { fasa gerak } \\
\text { dan fasa diam }\end{array}$ & 30 & 75 & 54 & 75 \\
$\begin{array}{l}\text { Mengevaluasi } \\
\text { terjadinya } \\
\text { pemisahan }\end{array}$ & 54 & 85 & 48 & 88 \\
$\begin{array}{l}\text { komponen } \\
\text { Intepretasi } \\
\text { data } \\
\text { percobaan }\end{array}$ & 60 & 86 & 44 & 90 \\
\hline & 51 & 82 & 49 & 84 \\
\hline
\end{tabular}

Berdasarkan data pada tabel 2 di atas menunjukkan bahwa metode demonstrasi yang dikembangkan dengan memadukan gambar dalam power point dapat meningkatkan hasil belajar mahasiswa dalam mempelajari kromatografi lapis tipis dan kromatografi kolom. Hal ini ditunjukkan oleh tes kemampuan sebelum dan sesudah penerapan metode, misalnya pada siklus I dari rata-rata 51 meningkat menjadi 82 untuk kromatografi lapis tipis KLT dan dari 49 menjadi 84 untuk kromatografi kolom adsorbsi KKA. Hal ini sesuai dengan hasil penelitian Shepardson et al. (1994) dan Muti'ah et al. (2016) bahwa metode demonstrasi yang dijalankan dengan baik dapat meningkatkan pemahaman, kemampuan dalam memprediksi, pengamatan, dan penjelasan suatu konsep dan meningkatkan kemampuan dalam mengerjakan tes hasil belajar. Meyer et al. (2003) juga melaporkan bahwa metode demonstrasi dalam pembelajaran sain dapat meningkatkan kemampuan siswa dalam menggabungkan berbagai konsep- konsep ilmiah.

Di samping aktivitas dan perhatian selama proses pembelajaran serta tes hasil belajar, presepsi mahasiswa terhadap metode demonstrasi yang diterapkan juga telah diujikan. Dari hasil uji/tes tanggapan mahasiswa dapat disimpulkan bahwa 55\% mahasiswa menyatakan sangat setuju, 38\% setuju, 7\% kurang setuju dan $1 \%$ menyatakan tidak setuju.

\section{SIMPULAN}

Kesimpulan yang diperoleh dari hasil penelitian ini adalah sebagai berikut: (1) Pendekatan Lesson Study pada pembelajaran Pemisahan Analitik terbukti dapat meningkatkan kualitas pembelajaran yaitu terbentuknya rasa kolegalitas, bersikap terbuka, belajar dari pengalaman nyata, adanya kerjasama untuk mengembangkan, saling membagi ide baru dan peningkatan perhatian, aktivitas, dan motivasi dalam pembelajaran. (2) Ditemukan 4 formulasi pada penerapan metode demonstrasi kimia yaitu: penguasaan materi, terjangkau seluruh mahasiswa, sinkronisasi hasil demonstrasi dan gambar pada power point, serta ketersediaan waktu. (3) Penerapan media demonstrasi kimia yang dipadu dengan gambar/konsep pada power point dapat meningkatan pemahaman mahasiswa dari 51 hingga 82 pada siklus I dan dari 49 menjadi 84 pada siklus II. 


\section{DAFTAR PUSTAKA}

Baddock, M. \& Bucat, R. (2008). Effectiveness of a classroom chemistry demonstration using the cognitive conflict strategy. International Journal of Science Education. 30(8), 1115-1128.

Buncick, M.C., Betts, P.G., \& Horgan, D.D. (2001). Using demonstrations as a contextual road map: enhancing course continuity and promoting active engagement in introductory college physics. International Journal of Science Education. 23(12), 1237-1255.

Bowen, C. W., \& Phelps, A. J. (1997). Demonstration based cooperative testing in general chemistry: Abroader assessmentof-learning technique. Journal of Chemical Education, 74(6), 715-719

Cochran-Smith, M. and S. L. Lytle. (2001). "Beyond Certainty: Taking an Inquiry Stance on Practice." In A. Lieberman, and L. Miller. (eds.). Teachers Caught in the Action: Professional Development that Matters. New York: Teachers College Press.

Chiappetta, E.L., \& T.R. Koballa. (2002). Science instruction in the middle and secondary schools. Upper Saddle River, NJ: PrenticeHall

Clermont, C.P., Borko, H., \& Krajcik, J.S. (1994). Comparative study of the pedagogical content knowledge of experience and novice chemical demonstrators. Journal of Research in Science Teaching. 31(4), 419441.

Chokshi, S. \& C. Fernandez. (2005). "Reaping the systemic benefits of lesson study: Insights from the U.S." Phi Delta Kappan 86 (9): 674-681.

Hendayana. (2006). Lesson Study: Suatu strategi untuk meningkatkan keprofesionalan Pendidik (Pengalaman INSTEP JICA: UPI Press

Miller, T.L. (1993). Demonstrationexplorationdiscussion: Teaching chemistry with discovery and creativity. Journal of Chemical Education 70 (3): 187-89.

Milne, C. \& Otieno, T. (2007). Understanding engagement: Science demonstrations and emotional energy. Science Education. 91(4), 523-553.

Meyer, L. S., Schmidt, S., Nozawa, F., Panee, D., \& Kisler, M. (2003). Using demonstrations to promote student comprehension in chemistry. Journal of Chemical Education. 80(4), 431-435.

Muti'ah, Siahaan J., \& Sukib. (2016). Efek Demonstrasi Kimia yang Dimodifikasi Dimodifikasi Terhadap Pemahaman Mahasiswa Pada Topik Elektrokimia, J. Pijar MIPA, Vol. XI No.2, September 2016: 81-86

Muti'ah, Siahaan J., \& Sukib. (2017). Media Demonstrasi Kimia Yang Dimodifikasi Dimodifikasi Untuk Mengatasi Miskonsepsi Mahasiswa Pada Topik Sel Ellektrokimia, $J$. Pijar MIPA, Vol. XII No.1, Maret 2017: 25-31

Lewis, C. (2004). "Lesson study." In L. B. Easton. (ed.). Powerful design for professional learning. Oxford. $\mathrm{OH}$ : National Staff Development Council, 135-148.

Putnam, R. T. and H. Borko. (2000). "What do you new view of knowledge and thinking have to say about research on teacher learning?" Educational Researcher 29 (1): 4-15.

Pierce, D. T., \& Pierce, T. W. (2007). Effective use of demonstration assessments in the classroom relative to laboratory topics. Journal of Chemical Education. 84(7), 1150-1155

Roadmck. M. D. (1993). Chemical demonstrations: leaming theories suggest caution, Journal of Chernical Education. 70, 1025 - 1028.

Shepardson, D. P., Moje, E. B., \& KennardMcClelland, A.M. (1994). The impact of a science demonstrationon children's understanding of air pressure. Journal of Research in Science Teaching, 31(3), 243-258

Shakhashiri, B. Z. (1992). Chemical demonstrations: a handbook for teachers of chemistry, volumes 1-5. Madison, WI: University of Wisconsin Press.

Saito, E., H. Harun, Ibrohim, I. Kuboki, \& H. Tachibana. (2006). Development of school based in-service teacher training under the Indonesian Mathematics and Science teacher Education Project. Improving School, 9(1): 47 - 59.

Stewart, R. A. \& J. L. Brendefur. (2005). "Fusing lesson study and authentic achievement: A model for teacher 
Chemistry Education Practice, 4 (3), 2021 - 293

Muti'ah, Loka, Muntari

collaboration." Phi Delta Kappan 86 (9):

681-687.

Sund. R. B.. dan L.W. Trowbridge. 1973. Teaching science by inquiry in the secondaw school ( 2nd ed.): Charles E. Merrill Publishing Company. A Bell \& HoweIl Company.

Tanis, D. O. (1984). Why 1 do dernonstr;itions. Journal of Chemical Education. 61.1010 $-1011$.

Taylor, C. A. (1988). The art and science of lecture demonstration. New York: Taylor \& Francis Group.

Valcarcel, M. (1992). A modern defi nition of analytical chemistry. Trends Anal. Chem.Vol. 16,:124-131

Valcarcel, M. \& M.D. Luquede Castro. (1995). A hierarchical approach to analytical chemistry. Trends Anal. Chem.Vol..14, :242-250

Wenzel, T.J. (1995). "A new approach to undergraduate analytical chemistry", Anal. Chem.Vol.67:.470-475

Wenzel, T. J. (1998). Cooperative group learning in undergraduate analytical chemistry. Analytical Chemistry, 70(23), 790A-795A 